\title{
Pengembangan Modul Berciri Pendekatan Kontekstual Dalam Pembelajaran Fisika pada Materi Tekanan
}

\author{
Atira, Unggul Wahyono, dan Sahrul Saehana \\ Atirasudirman066@gmail.com \\ Program Studi Pendidikan Fisika FKIP Universitas Tadulako \\ Jl. Soekarno Hatta Km. 9 Kampus Bumi Tadulako Tondo Palu - Sulawesi Tengah
}

\begin{abstract}
Abstrak - Penelitian ini dilakukan untuk menghasilkan modul dengan pendekatan kontekstual dalam pembelajaran fisika pada materi tekanan. Adapun tujuan dari penelitian ini adalah untuk mengetahui kelayakan modul dengan menganalisis tingkat kelayakan penyajian, bahasa serta kesesuaian materi dengan pendekatan kontekstual. Penelitian ini merupakan penelitian pengembangan yang mengacu pada model pengembangan 4D yang meliputi tahap define, design, development, dan disseminate. Modul yang dikembangkan cenderung menyajikan contoh kontekstual yang disesuaiakan dengan lingkungan siswa di SMP Negeri 3 Bambalamotu. Subjek penelitian uji coba keyakan modul dilakukan pada siswa SMPN 3 Bambalamotu kelas VIII ${ }^{A}$ yang berjumlah 20 orang. Hasil uji coba dan analisis angket menunjukan bahwa rata-rata skor penilaian ahli materi sebesar 3,21 dikategorikan "Baik", rata-rata skor ahli media sebesar 3,61 dikategorikan "Sangat Baik", analisis kelayakan oleh guru dengan skor rata-rata sebesar 3,35 dikategorikan "Sangat Baik" dan hasil analisis penilaian respon siswa diperoleh skor rata-rata sebesar 3,53 dan dikategorikan "Sangat Setuju". Hasil penelitian menunjukkan bahwa modul ajar yang dikembangkan layak dijadikan sebagai bahan ajar mandiri siswa.
\end{abstract}

Kata Kunci: Modul; Pendekatan kontekstual; Tekanan

\section{PENDAHULUAN}

Menurut pandangan secara umum, masih banyak siswa yang menganggap mata pelajaran fisika sebagai salah satu pelajaran yang sulit dipahami sehingga berdampak pada rendahnya hasil belajar siswa. Kesulitan yang sering terjadi dalam pembelajaran fisika antara lain banyak memuat hal-hal yang abstrak dan pemahamannya banyak melibatkan kemampuan gambaran mental. Selain itu, fisika menjelaskan gejala alam yang cenderung bersifat verbal sehingga kekurangan dalam bahasa dapat menimbulkan bias dalam memahami konsep fisika itu sendiri [1].

Berdasarkan observasi yang dilakukan di lapangan khususnya di SMP Negeri 3 Bambalamotu bahwa selama ini hanya mengandalkan fasilitas belajar yang diberikan oleh pemerintah saja sehingga sumber belajarnya sangat terbatas. Sampai saat ini siswa di SMP Negeri 3 Bambalamotu belajar hanya menggunakan buku IPA terbitan Ganeca exact, tanpa ada buku atau referensi lain yang bisa dijadikan pendukung pembelajaran misalnya modul, LKS, atau buku BSE. Penyajian isi di dalam buku tersebut berstandar nasional, artinya baik penyajian materi maupun penerapan contoh disajikan secara umum dan hanya sedikit membahas masalah yang kontekstual dengan lingkungan siswa sehingga siswa merasa materi yang disajikan abstrak dan sulit untuk dipahami secara langsung kecuali dengan pejelasan guru
Salah satu perangkat pembelajaran yang dianggap mampu meningkatkan hasil belajar adalah media belajar. Penggunaan media belajar harus dipertimbangkan dengan baik oleh guru demi menunjang motivasi belajar siswa. Pemilihan media sebagai sumber belajar mandiri dapat memperkaya pengalaman belajar dan membantu kesiapan siswa untuk mendapatkan materi yang akan diajarkan dipertemuan berikutnya.Media pembelajaran mandiri itu bercirikan self instructional (membelajarkan diri sendiri), self contained (satu kesatuan), stand alone (berdiri sendiri), adaptive (penyesuaian) dan user friendly (bersahabat) [2].

Modul merupakan sebuah bahan ajar yang disusun secara sistematis dengan bahasa yang mudah dipahami oleh peserta didik sesuai dengan tingkat pengetahuan dan usia mereka, sehingga mereka dapat belajar mandiri kemudian peserta didik dapat mengukur sendiri tingkat penguasaan mereka terhadap materi yang dibahas pada setiap satuan modul [3]. Perlu dikembangkan modul yang disesuaikan dengan kebutuhan siswa serta kondisi sekolah (kontekstual) agar siswa mudah memahami materi yang terdapat pada modul serta lebih mudah mengaitkan materi dengan contoh lain yang ada dilingkungan sekitar mereka sehingga kegiatan pembelajaran dapat berlangsung efektif dan menyenangkan.

Penelitian pengembangan modul yang telah ada saat ini diantaranya berbasis Problem Based Learning dan modul pembelajaran 
dengan menggunakan strategi inkuiri terbimbing yang mendeskripsikan kemenarikan, kemudahan, dan keefektifan produknya, namun peneliti merekomendasikan agar penelitian selanjutnya menyajikan contoh atau fenomena yang kontekstual, tidak terpaku pada fenomena yang ada dalam modul, serta sesuai dengan karakteristik siswa [4].

Modul berciri kontekstual merupakan salah satu pendekatan yang digunakan dalam pembelajaran. Pembelajaran berciri kontekstual adalah konsep belajar yang membantu guru mengaitkan antara materi pembelajaran dengan situasi dan kondisi dunia nyata siswa, dan mendorong siswa untuk menerapkannya dalam kehidupan sehari-hari. Mengaitkan ilmu dan pengalaman siswa dalam pembelajaran adalah salah satu karakteristik dari pembelajaran kontekstual. Pelajaran fisika dalam kehidupan sehari-hari sangat banyak kaitannya, oleh karena itu perlu diciptakan pembelajaran dengan pendekatan yang dirasa tepat. Pelaksanaan pembelajaran fisika dilakukan dengan membiasakan siswa untuk memperoleh pemahaman melalui pengalaman serta pengamatan terhadap contoh [5].

Berdasarkan uraian masalah di atas, diketahui bahwa perlunya penggunaan bahan ajar berupa modul dalam pembelajaran yang disusun secara jelas, menarik dan sistematis sehingga mampu meningkatkan minat belajar siswa, dan peneliti tertarik untuk mengembangkan bahan ajar berupa modul berciri kontekstual sebagai bahan pembelajaran mandiri yang dilengkapi dengan materi, contoh soal, latihan soal, serta soal evaluasi sehingga siswa dapat menggunakannya sebagai bahan pembelajaran mandiri.

\section{METODE PENELITIAN}

Penelitian ini merupakan penelitian pengembangan dengan menggunakan modifikasi model 4-D dari Thiagarajan, dkk (1974) yang terdiri dari empat tahap, diantaranya define (pendefinisian), design (desain), development (pengembangan), dan disseminate (penyebaran). Akan tetapi pengembangan modul kontekstual ini dilaksanakan sampai tahap Develop [6].

Penelitian dilakukan di SMP Negeri 3 Bambalamotu dengan jumlah responden 20 orang siswa kelas $\mathrm{VIII}^{\mathrm{A}}$. Instrumen pengumpulan data pada penelitian ini adalah menggunakan angket. Metode perolehan data yang digunakan adalah pemberian lembar angket validasi kepada ahli materi dan ahli media, angket evaluasi kelayakan oleh guru, serta angket respon siswa terhadap penggunaan modul.

Penentuan teknik analisa data untuk mengetahui nilai akhir pada setiap butir angket penelitian yaitu jumlah nilai yang diperoleh dibagi dengan banyaknya yang menjawab angket penilaian tersebut. Rumus untuk menghitung nilai rata-rata adalah sebagai berikut.

$$
\bar{X}=\frac{\sum x}{n}
$$

Keterangan:

$\bar{X} \quad$ : nilairata-rata tiap butir pertanyaan

$\sum x$ : jumlah nilai dari seluruh penilaian dalam tiap butir pertanyaan

\section{$n$ : banyaknya butir pertanyaan}

Mengubah skor rata-rata yang diperoleh menjadi nilai kualitatif berdasarkan klasifikasi penilaian dapat dilihat pada Tabel 1 [7].

TABEL 1 KATEGORI SKALA LIKERT

\begin{tabular}{cc}
\hline Skor Rata-Rata & Kriteria \\
\hline $3,25<\bar{X} \leqslant 4,00$ & Sangat Baik (SB) \\
$2,50<\bar{X} \leqslant 3,25$ & Baik (B) \\
$1,75<\bar{X} \leqslant 2,50$ & Kurang (K) \\
$1,00 \leqslant \bar{X} \leqslant 1,75$ & Sangat Kurang (SK) \\
\hline
\end{tabular}

\section{HASIL DAN PEMBAHASAN}

\section{A. Hasil Penelitian}

Tahap pertama yang dilakukan adalah define (pendefinisian). Pada tahap ini dilakukan analisis masalah di SMP Negeri 3 Bambalamotu dalam pembelajaran khususnya pada pelajaran IPA fisika. Pada tahap ini telah dilakukan wawancara secara langsung kepada kepala sekolah sekaligus sebagai guru fisika di SMPN 3 Bambalamotu untuk mendapatkan informasi yang selanjutnya akan dijadikan sebagai bahan pengembangan modul oleh peneliti. Hasil wawancara yang didapatkan diantaranya pembelajaran yang diterapkan di sekolah belum maksimal karena sumber belajar yang terbatas, motivasi siswa dalam belajar terbilang rendah, serta kemampuan siswa dalam menerima materi pada buku ajar masih perlu ditingkatkan. Materi IPA yang akan dikembangkan oleh peneliti adalah materi tekanan, alasan memilih materi tersebut karena penerapannya banyak ditemukan disekitar lingkungan siswa sehingga diharapkan lebih memudahkan siswa dalam mempelajari serta memahami isi modul. Pembelajaran itu ditunjukkan pada perubahan sikap sebagai hasil dari pengalaman. Berdasarkan pendapat tersebut menguatkan bahwa pembelajaran yang baik dan efektif adalah ketika siswa diberi 
pengalaman atau diajak melakukan pengamatan terhadap lingkungan sekitar yang membuat proses pembelajaran lebih bermakna [8].

Tahap kedua adalah design (perancangan). Adapun yang dilakuakan pada tahap ini diantaranya: 1) menyusun peta konsep atau peta kebutuhan modul digunakan sebagai acuan dalam mengembangkan isi modul secara sistematis, 2) Menyusun kerangka modul, 3) Menetapkan desain tampilan modul yang meliputi tampilan sampul, penentuan jenis dan ukuran huruf, dan penyususnan isi modul, 4) Mengumpulkan referensi dimana sebelum menyusun modul peneliti terlebih dahulu mengumpulkan beberapa referensi yang berkaitan dengan materi modul serta mengumpulkan gambar-gambar dan ilustrasi yang sesuai dengan materi modul. Ilustrasi bertujuan untuk memperjelas uraian materi pada modul dan sebagai penarik perhatian pembaca, 5) Menyusun instrumen penelitian modul yang meliputi lembar penilaian untuk ahli materi, media, guru, serta angket respon siswa. Pada lembar penilaian untuk ahli materi terdapat tiga aspek yaitu kelayakan isi, kelayakan penyajian, dan kesesuaian dengan pendekatan kontekstual, pada lembar penilaian ahli media terdapat dua aspek penilaian yaitu aspek kelayakan kegrafikan dan bahasa serta angket uji kelayakan oleh guru fisika terdiri dari aspek penyajian materi, aspek tampilan modul, dan aspek manfaat. Angket respon siswa dikembangkan menggunakan skala Likert dengan empat alternatif jawaban yaitu "sangat setuju", "setuju ", "tidak setuju", dan "sangat tidak setuju". Angket respon siswa tersebut terdiri dari aspek isi, penyajian, aspek bahasa, dan aspek kemenarikan.

Tahap ketiga adalah Develop (pengembangan). Adapun yang dilakukan pada tahap ini diantaranya:

\section{a. Menulis draft modul}

Penulisan draft modul meliputi sampul modul, kata pengantar, peta konsep, pendauluan, daftar simbol, daftar isi, daftar gambar, rencana pembelajaran, kegiatan belajar, glosarium, daftar pustaka serta sampul belakang.

b. Penyuntingan.

Setelah proses penulisan modul, diperoleh draft modul awal. Selanjutnya draft modul tersebut dikonsultasikan kepada dosen pembimbing dengan maksud medapatkan masukan saran perbaikan dan penyempurnaan modul. Draft modul yang dikonsultasikan tersebut selanjutnya diperbaiki sesuai saran pembimbing. Hal tersebut dilakukan oleh peneliti secara berulang sampai draft modul disetujui oleh pembimbing untuk divalidas kepada ahli materi dan ahli media.

c. Validasi/ Uji Kelayakan Produk

Pada tahap ini penulis melakukan validasi kepada ahli materi dan ahli media dengan maksud agar modul yang telah dikembangkan atas saran dan perbaikan dari dosen pembimbing dapat divalidasi sehingga peneliti dapat mengetahui kelemahan dan kekurangan produk. Selanjutnya peneliti meminta ahli materi, ahli media serta guru mata pelajaran fisika untuk mengevaluasi draft modul yang telah diberikan dengan cara mengisi angket lembar penilaian yang telah diberikan oleh peneliti. Adapun hasil validasi oleh ahli materi, ahli media dan guru dapat di lihat pada tabel 2, 3 , dan 4.

TABEL 2 HASIL VALIDASI KELAYAKAN OLEH AHLI MATERI

\begin{tabular}{|c|c|c|c|}
\hline No & Aspek Penilaian & $\begin{array}{c}\text { Rata-rata } \\
\text { jumlah nilai }\end{array}$ & Kategori \\
\hline 1 & Kelayakan Isi & 3,12 & Baik \\
\hline 2 & $\begin{array}{l}\text { Kelayakan } \\
\text { Penyajian }\end{array}$ & 3,13 & Baik \\
\hline \multirow[t]{2}{*}{3} & $\begin{array}{l}\text { Kesesuaian dengan } \\
\text { pendekatan } \\
\text { kontekstual }\end{array}$ & 3,39 & Sangat Baik \\
\hline & Rata-rata & 3,21 & Baik \\
\hline \multicolumn{4}{|c|}{ TABEL 3 HASIL VALIDASI OLEH AHLI MEDIA } \\
\hline No & Aspek Penilaian & $\begin{array}{c}\text { Rata-rata } \\
\text { jumlah nilai }\end{array}$ & Kategori \\
\hline 1 & $\begin{array}{l}\text { Kelayakan } \\
\text { kegrafikan }\end{array}$ & 3,56 & Sangat baik \\
\hline 2 & Kelayakan bahasa & 3,66 & Sangat Baik \\
\hline & Rata-rata & 3,61 & Sangat Baik \\
\hline & TABEL 4 HASIL ANA & ISIS KELAYAKAN GU & \\
\hline No & Aspek Penilaian & $\begin{array}{c}\text { Rata-rata } \\
\text { jumlah nilai }\end{array}$ & Kategori \\
\hline 1 & Isi & 3,80 & Sangat baik \\
\hline 2 & Tampilan & 3,25 & Sangat Baik \\
\hline 3 & $\begin{array}{l}\text { Keterlaksanaan } \\
\text { dalam } \\
\text { pembelajaran }\end{array}$ & 3,00 & Baik \\
\hline & Rata-rata & 3,35 & Sangat Baik \\
\hline
\end{tabular}

\section{d. Revisi Produk}

Revisi produk dilakukan setelah produk dinilai oleh ahli. Adapun saran dan komentar dari masing-masing validator dijadikan sebagai bahan revisi oleh peneliti.

\section{e. Uji Coba Produk}

Pada tahap ini dilakukan uji coba terbatas di SMP Negeri 3 Bambalamotu. Hasil uji coba yang dilakukan terhadap 20 siswa kelas VIII $^{A}$ menunjukkan bahwa modul ajar dengan pendekatan kontekstual sangat layak untuk digunakan dalam proses pembelajaran fisika dengan skor rata-rata hasil analisis respon 
siswa sebesar 3,53 dan dikategorikan "Sangat Setuju".

\section{B. Pembahasan}

Penelitian pengembangan modul dengan pendekatan kontekstual pada materi tekanan untuk siswa SMP kelas VIII ${ }^{\mathrm{A}}$ ini bertujuan untuk mengetahui manfaat serta kelayakannya dalam proses pembelajaran fisika, dapat menjadi acuan guru dalam usaha memperbaiki kualitas pembelajaran, dan juga dapat dijadikan tambahan referensi untuk penelitian selanjutnya tentang pengembangan modul ajar dengan pendekatan kontekstual. Analisis data hasil pengembangan modul ajar ini didasarkan pada hasil validasi dan uji coba terbatas. Desain uji coba yang digunakan dalam penelitian ini adalah uji kelayakan terhadap produk. Uji coba dilakukan oleh satu dosen fisika sebagai ahli materi, satu dosen fisika sebagai ahli media, satu orang guru fisika SMP Negeri 3 Bambalamotu yang menganalisis kelayakan pengguanaan modul serta dua puluh siswa kelas VIII ${ }^{A}$ SMP Negeri 3 Bambalamotu.

Berdasarkan penilaian ahli materi yang dilakukan oleh dosen fisika universitas tadulako yaitu bapak Drs.H.Muhammad Ali,M.Si, aspek yang dinilai dari modul ini meliputi kelayakan isi, kelayakan penyajian, dan kesesuaian dengan pendekatan kontekstual. Rata-rata hasil penilaian dari uji kelayakan isi adalah 3,12, rata-rata dari uji kelayakan penyajian adalah 3,13 , dan rata-rata penilaian dari uji kesesuaian dengan pendekatan kontekstual adalah 3,39. Hasil rata-rata penilaian uji kelayakan isi, uji kelayakan penyajian dan uji kesesuaian dengan pendekatan kontekstual didapatkan jumlah rata-rata keseluruhan dari ahli materi yaitu 3,21 dan dikategorikan "Baik ". Dari hasil tersebut ahli materi menyatakan bahwa bahan ajar ini layak di uji cobakan di lapangan tanpa revisi.

Hasil penilaian ahli media yang dilakukan oleh dosen fisika universitas tadulako yaitu bapak Muhammad Jarnawi, M.Pd, aspek yang dinilai dari modul ini meliputi kelayakan kegrafikan dan kelayakan bahasa. Rata-rata hasil penilaian dari uji kelayakan kegrafikan 3,56 dan rata-rata dari uji kelayakan bahasa adalah 3,66. Hasil rata-rata penilaian uji kelayakan kegrafikan dan uji kelayakan bahasa didapatkan jumlah rata-rata keseluruhan dari ahli media yaitu 3,61 dan dikategorikan "Sangat Baik". Dari hasil tersebut ahli media menyatakan bahwa bahan ajar ini layak di uji cobakan di lapangan dengan revisi sesuai saran.

Selanjutnya dilakukan uji kelayakan penggunaan modul kepada guru fisika di SMP
Negeri 3 Bambalamotu yaitu bapak Samsul Bahri, S.Pd, aspek yang dinilai dalam kelayakan penggunaan ini adalah isi/materi, tampilan modul serta keterlaksanaan pembelajaran modul. Rata-rata hasil penilaian dari uji kelayakan isi 3,80, rata-rata dari kelayakan tampilan adalah 3,25 dan rata-rata hasil penilaian keterlaksanaan pembelajaran adalah 3,00 . Hasil rata-rata penilaian uji kelayakan isi, tampilan dan keterlaksanaan pembelajaran didapatkan jumlah rata-rata keseluruhan dari guru yaitu 3,35 dan dikategorikan " Sangat Baik".

Hasil di atas menunjukkan bahwa modul ini memungkinkan siswa untuk belajar secara mandiri karena di dalam modul ini telah dilengkapi dengan materi yang sesuai dengan tema maupun Standar Kompetensi dan Komptensi Dasar, terdapat contoh dan ilustrasi yang disajikan secara kontekstual artinya materi yang disajikan sesuai dengan lingkungan siswa, terdapat soal-soal latihan, diskusi, lemabar kerja siswa, rangkuman materi yang membuat siswa dapat mengetahui tingkat penguasaan materi serta umpan balik yang memungkinkan siswa untuk mengukur kemampuannya sendiri. Hasil ini menunjukkan bahwa modul ini dapat digunakan oleh siswa dalam proses pembelajaran karena menyajikan permasalahan yang kontekstual dengan lingkungan sehingga siswa mudah memahami materi.

Setelah dilakukan penilaian oleh ahli materi, media dan guru tahap selanjutnya dilakukan uji terbatas dengan tujuan untuk mengetahui respon siswa terhadap penggunaan modul ajar. Hasil pengembangan modul ajar diujikan dalam uji coba lapangan skala kecil kepada dua puluh siswa. Tujuan pelaksanaan uji coba lapangan skala kecil adalah untuk mendapatkan gambaran respon siswa terhadap modul ajar yang dikembangkan. Siswa memberi tanggapan terhadap materi, bahasa, dan ketertarikan menggunakan modul ajar tersebut. Hasil analisis respon siswa terhadap modul dengan pendekatan kontekstual pada materi tekanan yang dikembangkan disajikan dengan menggunakan tipe pernyataannya bersifat positif, nilai (score) untuk tiap pilihan jawabannya adalah sebagai berikut : 4; Sangat setuju, 3; Setuju, 2; Tidak setuju, 1; Sangat tidak setuju.

Uji terbatas dilakukan terhadap dua puluh siswa kelas VIII ${ }^{\mathrm{A}}$ SMP Negeri 3 Bambalamotu, siswa diberi angket yang mempunyai 18 item pernyataan dan ada 4 opsi pilihan. Setelah melakukan analisis didapatkan skor rata-rata sebesar 3,53. Berdasarkan Tabel 3.2 yaitu kriteria kategori respon siswa, skor tersebut 
termasuk ke dalam kategori "Sangat Setuju". Karena hasil angket menunjukkan kategori sangat setuju maka bisa dikatakan bahwa modul ajar yang dibuat layak digunakan sebagai media belajar siswa.

Berdasarkan uraian di atas maka modul dengan pendekatan kontekstual menggunakan konteks nyata dimaksudkan untuk membiasakan siswa bahwa apa yang dipelajari di sekolah sangat banyak manfaatnya untuk kehidupan nyata, materi yang dipelajari di sekolah bukanlah materi abstrak yang tidak ada kaitannya dengan kehidupan sehari-hari. Hal ini sesuai dengan pendapat Sinta wati dalam komentarnya pada angket respon siswa "Saya mengerti tentang modul ini, karena di dalam modul ini terdapat contoh dalam kehidupan sehari-hari. Jadi bagi saya sangat gampang untuk memahami modul ini". Modul dengan pendekatan kontekstual pada materi tekanan membuat siswa aktif untuk mengkonstruksi pengetahuan dan pemahaman mereka sendiri. Pembelajaran yang menggunakan pendekatan kontekstual memiliki karakteristik antara lain kerjasama, belajar mandiri, mempertimbangkan kondisi, karakteristik siswa, saling menunjang, menyenangkan, tidak membosankan, serta memanfaatkan lingkungan tempat tinggal sebagai sumber belajar. Hasil penelitian ini didukung oleh pendapat yang menyatakan bahwa penggunaan modul dalam pembelajaran fisika lebih efektif untuk meningkatkan motivasi belajar serta meningkatkan kemampuan kognitif siswa [9].

Penelitian pengembangan modul pada materi tekanan secara keseluruhan sangat layak digunakan sesuai dengan penilaian oleh ahli, guru dan siswa serta dapat memudakan siswa dalam memahami materi tekanan dengan mengaitkannya dalam kehidupan sehari-hari. Namun hal tersebut tidak lepas dari keterbatasan-keterbatasan peneliti selama melaksanakan penelitian ini, diantaranya peneliti masih terbatas pada satu sekolah saja dan belum dilakukan uji coba di sekolah yang berbeda. Selain itu keterbatasan waktu peneliti sehingga uji coba tidak dilakukan secara tuntas dan penyebaran angket respon siswa dilakukan di luar jam pelajaran.

\section{KESIMPULAN}

Berdasarkan hasil analisis dan pembahasan, maka dapat disimpulkan bahwa Pada hasil uji coba ahli materi didapatkan skor penilaian rata-rata sebesar 3,21 dan dikategorikan "Baik", analisis penilaian ahli media didapatkan skor rata-rata sebesar 3,61 dan dikategorikan "Sangat Baik", analisis uji kelayakan oleh guru didapatkan skor rata-rata sebesar 3,35 dan hasil analisis penilaian respon siswa didapatkan skor rata-rata sebesar 3,53 dan dikategorikan "Sangat Setuju". Hal ini menunjukkan bahwa modul yang dikembangkan ini dapat dijadikan sebagai salah satu bahan ajar mandiri bagi siswa.

\section{DAFTAR PUSTAKA}

[1] Prima, R. (2013). Pengembangan Modul Elektronik Fisika Sebagai Media Instruksional Pokok Bahasan Hukum Newton pada Pembelajaran Fisika di SMA. Probolinggo: Universitas JEMBER.

[2] Depdiknas. (2008). Teknik Penyusunan Modul. Jakarta: Direktorat Jenderal Manajemen Pendidikan Dasar dan Menengah.

[3] Multyaningsih, E. (2011). Riset Terapan Bidang Pendidikan \& Teknik. Yogyakarta: UNY Press

[4] Mirantika,R Ertikanto, dkk. (2015). Pengembangan Modul Pengembangan Materi Fluida Statis dengan Strategi Inkuiri Terbimbing. Bandar Lampung:Universitas Unila.

[5] Nasiroh,D. (2014). Pengembangan Modul dengan Pendekatan Kontekstual pada Materi Barisan dan Deret untuk Siswa SMP Terbuka Kelas IX. Jogjakarta: Universitas Negeri Yogyakarta.

[6] Buhari, B. (2011). Four D Model (Model Pengembangan Perangkat Pembelajaran dari Thiagarajan, dkk).

[Online]. Tersedia:

http://bustangbuhari.wordpress.com/2011/08/25/fourd-model-model-pengembangan-perangkatpembelajaran-dari-thigarajan-dkk/. [10 Februari 2016].

[7] Supandi, M. (2015). Pengembangan Komik Berbasis Etnosience pada Pembelajaran Fisika SMP Pokok Bahasan Kalor. Skripsi tidak diterbitkan. Palu: Program Studi Pendidikan Fisika FKIP Universitas Tadulako.

[8] Rosa,F. (2015). Pengembangan Modul Pembelajaran IPA SMP pada Materi Tekana Berbasis Keterampilan Proses Sains. Lampung: Unviersitas Muammadiyah Metro.

[9] Sarwanto. (2012). Pengembangan Modul Fisika Berbasis Problem Based Learning pada Materi Fluida untuk Siswa Cerdas IstimewA Berbakat Istimewa. Surakarta:Universitas Sebelas Maret. 